\title{
Kondroblastom ve kondromiksoid fibrom: Klinik, radyolojik, histolojik özellikleri ve tedavi prensipleri
}

\author{
Chondroblastoma and chondromyxoid fibroma: clinical, radiological, \\ histological features and principles of treatment
}

Turgay Er

isOM İstanbul Ortopedi Merkezi, İstanbul

\begin{abstract}
Kondroblastom ve kondromiksoid fibrom oldukça nadir görülen selim kemik tümörlerinden olup kıkırdak hücresinden köken alırlar. Her iki tümör de Enneking sınıflamasına göre Evre 2 yani aktif lezyon olarak değerlendirilir. Kondroblastom genellikle adolesan çağda ortaya çıktı ̆ı, uzun kemiklerin epifizinde yerleştiği ve direkt grafilerde pek kolay görülemediği için, çoğu zaman nonspesifik eklem ağrısı sanılarak takip edilir ve tedavi süreci gecikebilir. Ancak kondroblastomun bilgisayarlı tomografi ve manyetik rezonans görüntüleri oldukça tipiktir. Bu nedenle, epifizleri henüz kapanmamış hastalarda eklem ağrıları ısrarcı olursa, ileri görüntüleme yöntemleri uygulanarak kondroblastom olasılığı araştırılmalıdır. Kondromiksoid fibromun ise gerek klinik gerekse radyolojik bulguları çok tipik değildir. Fakat biyopsi yapıldığında lezyonda kondroid, miksoid ve fibromatöz dokuların görülmesi tanıyı kolaylaştırır. Her iki tümörün de tedavisi cerrahi olup genellikle küretaj ve grefonaj yapılır. Kondroblastomun küretajı yapılırken çok dikkatli olunmalıdır. Zira küretaj yapılırken fiz hattı zedelenebilir veya eklem içine girilerek eklem kontamine edilebilir. Aktif tümörler olmaları nedeniyle cerrahi sonrası nüks oranları yüksektir. Bu nedenle, nüks olasılığını azaltmak için, küretaj ardından fenol ya da sıvı azot gibi bir adjuvan uygulanır.
\end{abstract}

Anahtar sözcülkler: kondroblastom; kondromiksoid fibrom; kıkırdak hastalıkları

\begin{abstract}
Chondroblastoma and chondromyxoid fibroma are quite rare and benign bone tumors that originate in cartilage tissue. Both tumors are considered Stage 2 -active lesions- according to the Enneking's staging system. Due to its initial appearance in adolescence, its placement in the epiphysis of long bones, and the difficulty of its identification on radiography, chondroblastoma may be diagnosed and followed as nonspecific joint pain and its treatment may be delayed. However, the computerized tomography and magnetic resonance images of chondroblastoma are quite typical. Therefore, if patients with present epiphysis not yet closed and persistent joint pain, the possibility of chondroblastoma should be inquired by further imaging techniques. In contrast, chondromyxoid fibroma does not present with typical clinical or radiological symptoms. However, observing chondroid, myxoid and fibromatosis tissue during biopsy facilitates proper diagnosis. For both tumors, the treatment is surgical with curettage and bone grafting. The curettage of chondroblastoma should be performed with utmost caution, since the procedure can damage the epiphyseal plate or enter the joint and contaminate the area. The recurrence rate after surgery is high since these are both being active tumors. Thus, to reduce the possibility of recurrence, an adjuvant such as phenol or liquid nitrogen is applied after curettage.
\end{abstract}

Key words: chondroblastoma; chondromyxoid fibroma; cartilage diseases

\section{KONDROBLASTOM}

Kondroblastom kıkırdak hücrelerinden köken alan ve oldukça nadir görülen bir selim kemik tümörüdür. Tüm kemik tümörlerinin \%1'inden daha azını, selim kemik tümörlerinin ise \%9'unu teşkil eder. [1] ilk olarak Codman tarafından tanımlandığından dolayı Codman tümörü olarak da adlandırılır. ${ }^{[2]}$ Ancak Codman bu tümörü dev hücreli tümörün bir

varyasyonu olarak yorumlamış, daha sonra yapılan değerlendirmelerde gerek histolojik yapısı gerekse klinik seyrinin farklı olduğu görülerek, kondroblastom adı verilmiştir. Kondroblastom çoğunlukla büyük uzun kemiklerin epifizlerinde yerleşir. Sıklık sırasına göre proksimal humerus, distal femur, proksimal femur ve proksimal tibia en sevdiği lokalizasyonlardır. El ve ayağın küçük kemikleri ile talus ve kalkaneusta

- İletişim adresi: Turgay Er, iSOM İstanbul Ortopedi Merkezi, Çilekli Cad. No:1, 3. Levent, Beşiktaş, İstanbul Tel: 0542 - 5235789 e-posta: turgay_er@yahoo.com

- Geliş tarihi: 27 Eylül 2013 Kabul tarihi: 27 Eylül 2013 
da \%10 oranında görülür. ${ }^{[1]}$ Hastaların \%80’i epifiz hatları kapanmamış hastalardır. Yirmi beş yaş üzerinde görülmesi çok nadirdir. Erkeklerde iki kat daha sık rastlanır. ${ }^{[3]}$

\section{Klinik bulgular}

En önemli bulgu uzun zamandan beri devam eden ve çok şiddetli olmayan ağrıdır. Ağrı, lezyonun komşu olduğu eklemde olup aktivite ile yoğunluğu değişmez. Ayrıca eklemde effüzyon, hareket kısıtlılığı, kas atrofisi ve aksama diğer görülebilecek bulgulardır.

\section{Görüntüleme}

Kondroblastom direkt radyografilerde epifiz içinde eksentrik olarak yerleşmiş, ince bir sklerotik kenar ile çevrili litik alan şeklinde görülür (Şekil $1 \mathrm{a}, \mathrm{b}$ ). Olguların yarıdan fazlasında lezyon epifiz hattını geçer.
Yuvarlak ya da oval şekilli lezyon epifiz genişliğinin yarısı kadar büyüklüğe ulaşabilir. Kortekste ekspansiyona neden olabilir. Hastaların \%30'unda, lezyonun içinde noktasal tarzda kalsifikasyonlar görülür ve bu kalsifikasyonlar yaş ilerledikçe çoğalır. Kondroblastomların \%15-20'sinde anevrizmal yapı olup, radyolojik görünüm balonlaşma şeklinde ortaya çıkabilir. ${ }^{[4]}$

Konvansiyonel radyografi ile lezyon görüldükten sonra sınırlarını ve içeriğini daha iyi değerlendirebilmek için ileri tetkikler yapılabilir. Bilgisayarlı tomografi (BT) ile lezyonun korteks ile ilişkisi daha detaylı görülür. Ayrıca direkt grafide tam seçilemeyen noktasal kalsifikasyonlar da görüntülenebilir. Manyetik rezonans (MR) görüntüleme lezyonun epifiz ve eklem ile ilişkisini değerlendirebileceği gibi peritümöral ödemin de ortaya konmasına yardımcı olur (Şekil 2 a,b) (Şekil $3 a-c)$.
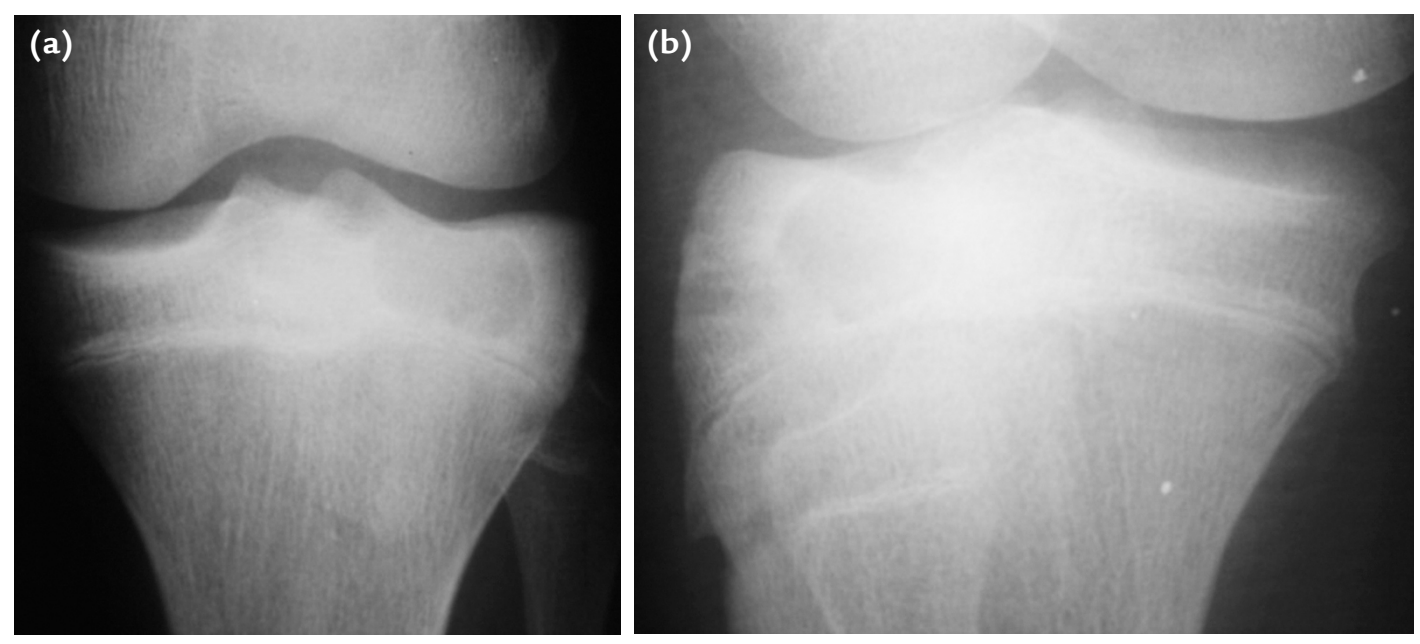

Şekil 1. a, b. On dört yaşında erkek hasta. Sol tibia proksimal epifiz içinde anterolateral yerleşmiş ince bir sklerotik kenar ile sınırlı oval şekilli litik lezyon.
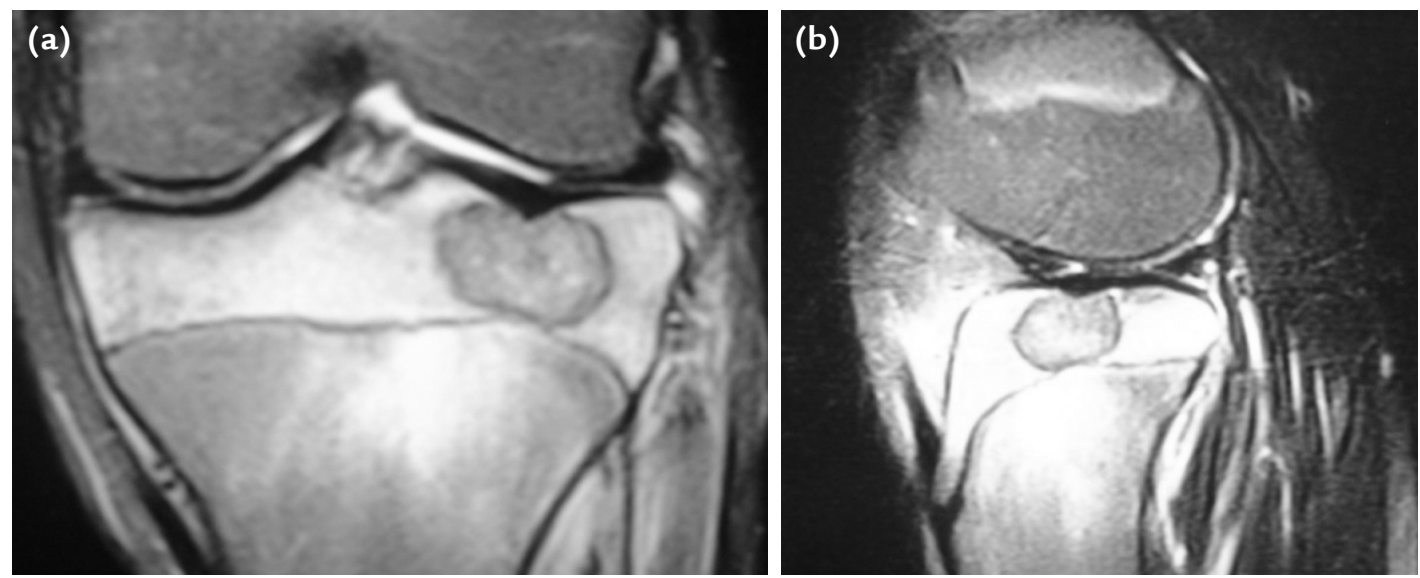

Şekil 2. a, b. Tibia üst uç epifizi içinde yerleşmiş kondroblastomun MR görüntüleri. Lezyonun eklem kıkırdağı ve epifiz hattı ile olan ilişkisi ve peritümöral ödem daha detaylı değerlendirilebilir. 

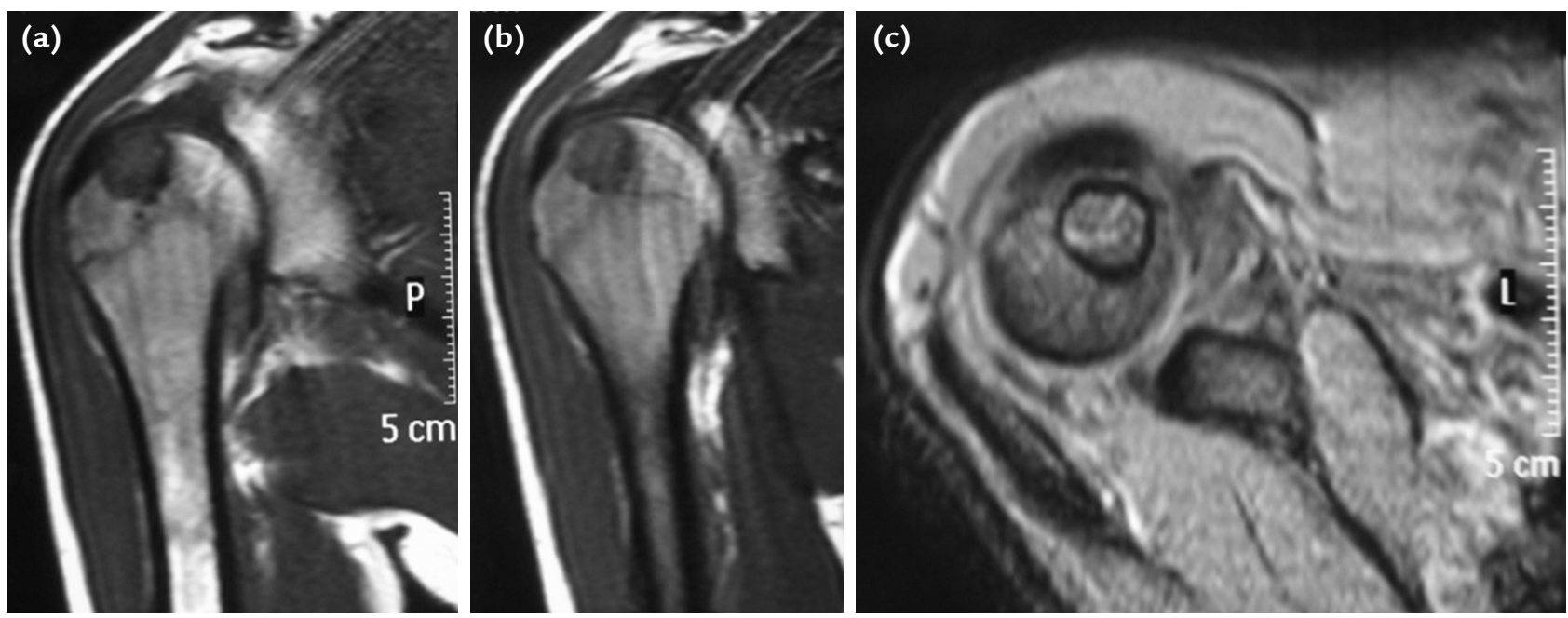

Şekil 3. a-c. Humerus üst uç epifizi içinde yerleşmiş kondroblastomun koronal ve aksiyel MR görüntüleri lezyonun eklem ile olan yakın komşuluğunu detaylı olarak ortaya koyuyor.

\section{Histopatoloji}

Makroskopik görünüm olarak yumuşak kıvamlı, sarı gri renkli, yer yer kanamalı doku şeklinde görülür. Kondroblastom epifiz plağını geçip metafize doğru ilerlediğinde, tümöral materyalin içinde destrüksiyona uğramış kıkırdak dokusu saptanır. ${ }^{[5]}$

Kondroblastomun mikroskopik görünümü oldukça sellüler, yuvarlak ve poligonal kondroblast benzeri hücrelerden oluşan, kısmen indiferansiye bir doku ile çevrilmiş, tam olgunlaşmamış kıkırdak matriks nodülleri şeklindedir. Mitoz nadiren görülür. İntersellüler kalsifikasyon odaklarına da rastlanır (Şekil 4). ${ }^{[5]}$

\section{Ayırıcı tanı}

Epifiz yerleşimli lezyonlar pek fazla olmadığı için genellikle ayırıcı tanı kolay olur. En sık karışabileceği lezyon clear cel/ kondrosarkomdur. Radyolojik olarak ayırt edebilmek çok zordur. Dev hücreli kemik tümörü de epifiz yerleşimli bir tümördür; ancak bu tümör kondroblastomun aksine genellikle epifizler kapandıktan

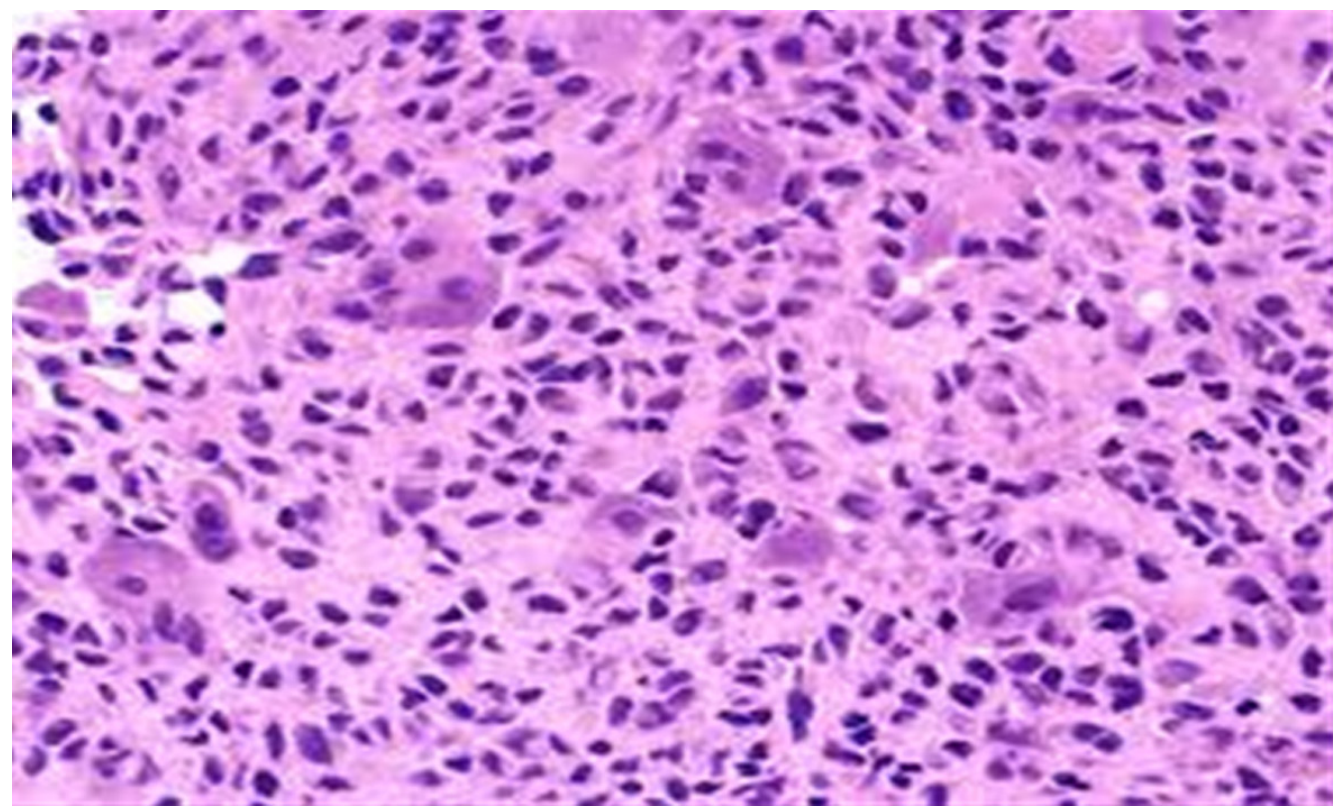

Şekil 4. Kondroid ara madde içinde yerleşmiş tek ve çok çekirdekli kondroblastlar. 
sonra ortaya çıkar. Nadir olarak kemik içi abse, sinovit, osteonekroz ve intraosseöz gangliyon da kondroblastom ile karıştırılabilir (Şekil 5 a-d).

\section{Tedavi}

Kondroblastomun tedavisi cerrahidir. Küretaj ve sonrasında oluşan defekt için grefonaj uygulanabilir. Nüks oranı \%10-15 arasındadır. Nüks olasılığını azaltmak için fenol ya da sıvı azotun adjuvan olarak kullanılması önerilir. Şayet nüks oluşursa tekrar küretaj ve grefonaj yapmak gerekir.
Lezyon, lokalizasyonu gereği eklem kıkırdağı ve epifız hattına oldukça yakın komşuluk gösterir. Bu nedenle cerrahi sırasında bu bölgelere zarar vermemeye özellikle dikkat etmek gerekir. Transmetafizyel yaklaşım yapılabileceği gibi femur üst uç gibi zor lokalizasyonlarda intraartiküler girilerek trap-door tekniği ile küretaj uygulanabilir. ${ }^{[4]}$

Kondroblastom çok nadir olarak akciğer metastazı yapabilir. Bu durumda metastatektomi yapılması gereklidir. Kemoterapi ve radyoterapinin tedavide yeri yoktur. ${ }^{[4]}$
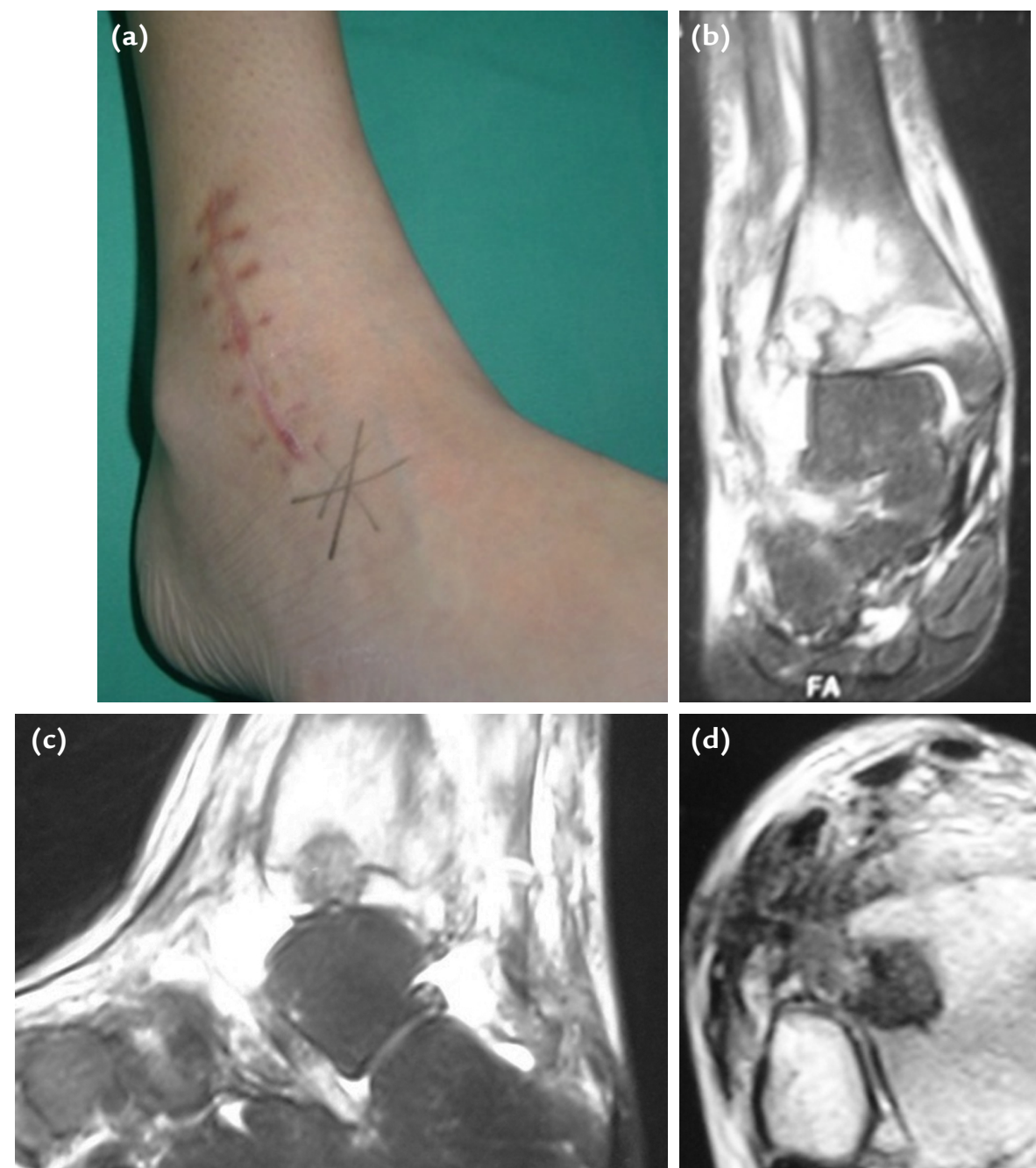

Şekil 5. a-d. Tibia alt uçta yerleşmiş kondroblastom. Sinovit ön tanısı ile sinoviyektomi yapılarak yetersiz cerrahi uygulanmış.

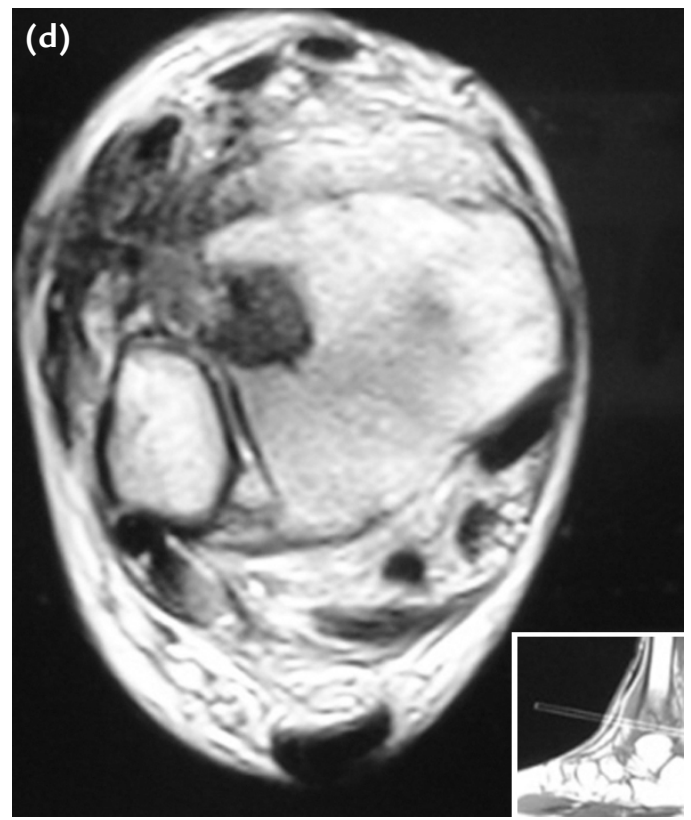




\section{KONDROMIKSOID FIBROM}

Son derece nadir görülen bir selim tümördür. Kondroid, fibröz ve miksoid yapılar içerir. Bütün kemik tümörlerinin $\% 0,5^{\prime}$ ini, selim kemik tümörlerinin ise \%2'sini teşkil eder. ${ }^{[1]}$ Genellikle 5-30 yaş arasında görülür. Kondroblastom gibi 30 yaş üzerinde görülmesi çok nadir iken kondroblastomun aksine 10 yaş altında görülmesi oldukça sıktır. ${ }^{[5]}$ Erkeklerde iki kat daha sık rastlanır. Kondromiksoid fibrom olgularının \%75'inden fazlası pelvis ve alt ekstremitede görülür. Üçte biri diz çevresinde, \%17 civarı da el ve ayaklardaki kısa kemiklerde yerleşir. ${ }^{[3]}$ Lezyonun uzun kemiklerde tercih ettiği bölge metafizdir.

\section{Klinik bulgular}

Uzun zamandan beri devam eden orta şiddette ağrı ve kemikte ele gelen şişlik başlıca klinik bulgulardır. Özellikle küçük kemiklere yerleştiğinde yumuşak doku kitlesi de oluşturabilir. Patolojik kırık görülmesi nadirdir.

\section{Görüntüleme}

Direkt grafilerde genellikle metafiz bölgesinde eksentrik yerleşmiş, ince sklerotik bir kenar ile çevrili, yaklaşık 3-4 cm çapında, oval ya da yuvarlak lobüle görünümlü coğrafi patern gösteren litik lezyon şeklindedir (Şekil 6 a, b). Bazen içinde septalar görülebilir. Kortekse yakın yerleşmiş ise kemiğin kenarını bombeleştirebilir. Bazen korteksi o kadar inceltir ki, direkt grafilerde korteks tamamen kaybolmuş olarak görülebilir. ${ }^{[5]}$

MR ile daha detaylı görünüm sağlanabilir. Lezyonun içeriğindeki kondroid, fibröz ve miksoid yapıları MR ile ayırt etmek mümkün olabilir. Genel olarak tüm kıkırdak kökenli tümörlerde görülen T1-ağılıklı görüntülerde düşük, T2-ağırlıklı olanlarda ise yüksek sinyal yoğunluğu göze çarpar (Şekil 7 a-e).

\section{Histopatoloji}

Kondromiksoid fibrom makroskopik olarak kısmen saydam gri-beyaz renkli hiyalin kıkırdağa benzer görünüme sahiptir. Kitle lobüller şeklinde olup, komşu kemikten keskin bir kenarla ayrılmıştır (Şekil 8 a).

Mikroskopik görünüm yoğun miksoid ve kondroid ara madde içinde yerleşmiş iğsi veya yıldız şeklinde hücrelerden ibarettir. Genellikle mitoz yoktur. Mikroskopta küçük büyütme ile bakıldığında lobüller şeklinde görülür (Şekil 8 b). ${ }^{[5]}$

\section{Ayırıcı tanı}

Her ne kadar radyolojik görünüm kondromiksoid fibrom tanı olasılığını güçlendirse de bazen anevrizmal kemik kisti, fibröz displazi ve nonossifiye fibrom ile ayırıc tanı yapmak zor olabilir. Anevrizmal kemik
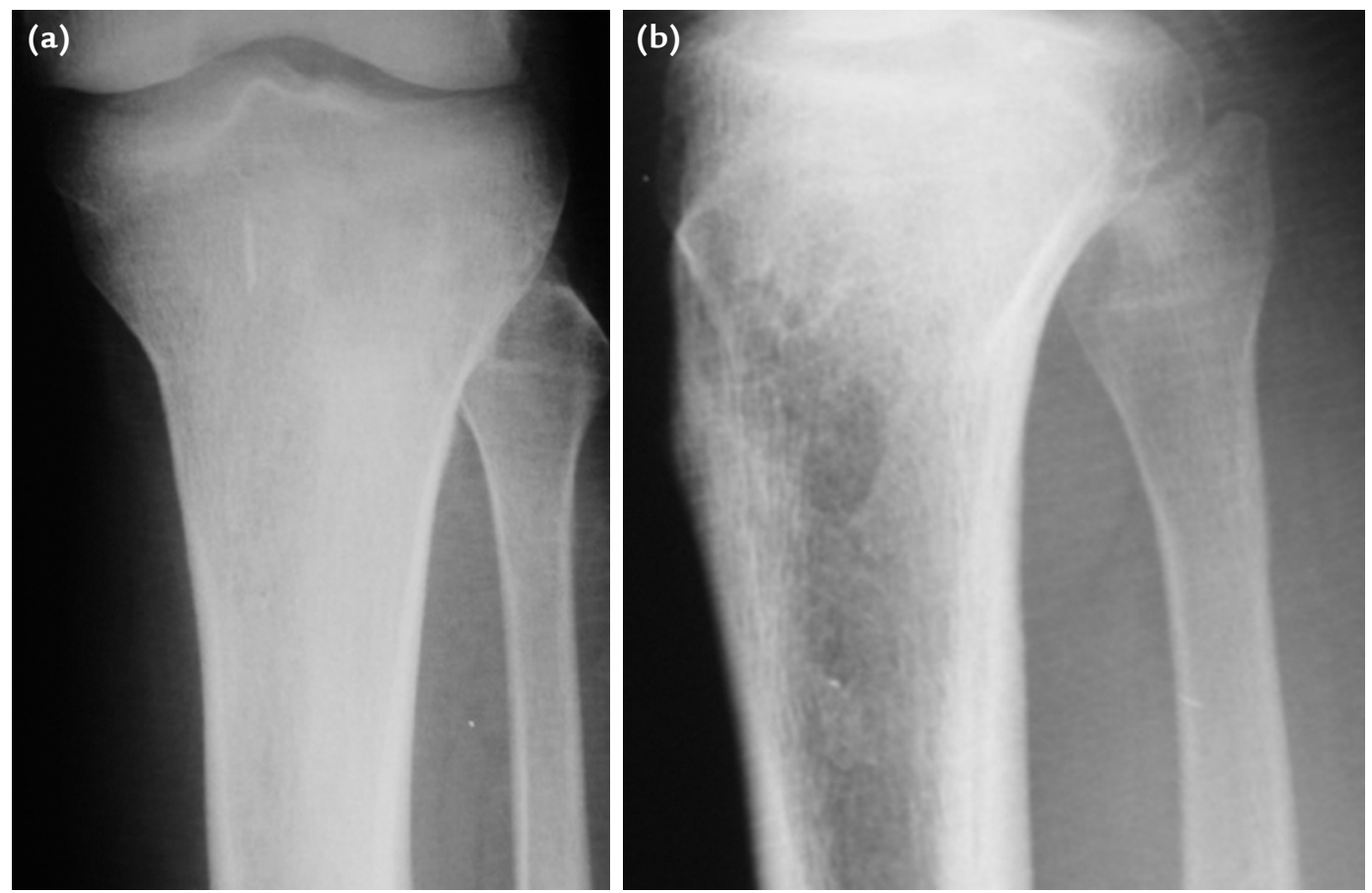

Şekil 6. a, b. Tibia üst uç metafizinde yerleşmiş kondromiksoid fibrom. Anteroposterior grafide net izlenememesine karşın lateral grafide metafiz yerleşimli, eksantrik lobüle lezyon görülebiliyor. 

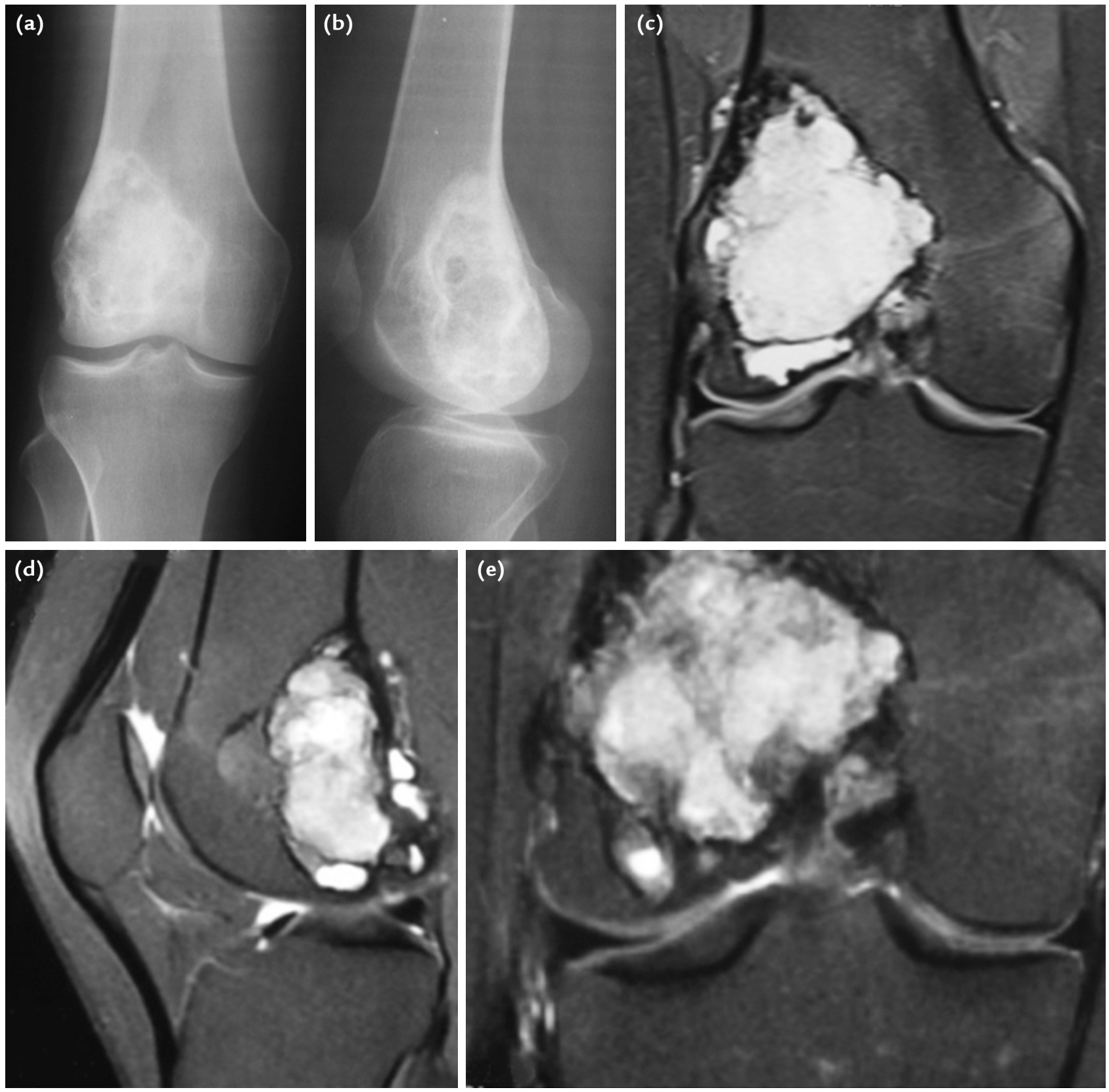

Şekil 7. a-e. Femur alt uç yerleşimli kondromiksoid fibrom. Konvansiyonel radyografilerde metafiz yerleşimli litik lezyon görülüyor (a, b). T2-ağırlıklı MR kesitlerinde lezyonun yüksek sinyal yoğunluğu oluşturduğu izleniyor (c-e).

kisti ile radyolojik ayırıcı tanı çoğu zaman mümkün olmayabilir, fibröz displazi ise daha santral yerleşimli olup karakteristik buzlu cam görünümüne sahiptir. Nonossifiye fibromda da kortikal bombeleşme ve periost reaksiyonu görülmesi son derece nadirdir. Dev hücreli tümör de ayırıcı tanıda düşünülmesi gereken bir lezyondur. Bu tümörde geçiş zonunun daha silik olması tanıyı kolaylaştııı. Histopatolojik olarak da miksoid kondrosarkom ve kondroblastom ayırıcı tanıda düşünülmesi gereken lezyonlardır.

\section{Tedavi}

Kondromiksoid fibrom Evre 2 lezyondur. Tedavisi öncelikle intralezyonel küretajdır. Küretajı takiben otogreft, allogreft veya kemik yerine kullanılan biyomateryaller ile grefonaj yapılabilir. Küretaj sonrası nüks oranı $\% 12,5$ ile $\% 25$ arasında değişmektedir. ${ }^{[3]}$ Tekrarlayan nüksler veya agresif seyir izleyenlerde lokal rezeksiyon ve rekonstrüksiyon yapılabilir. 

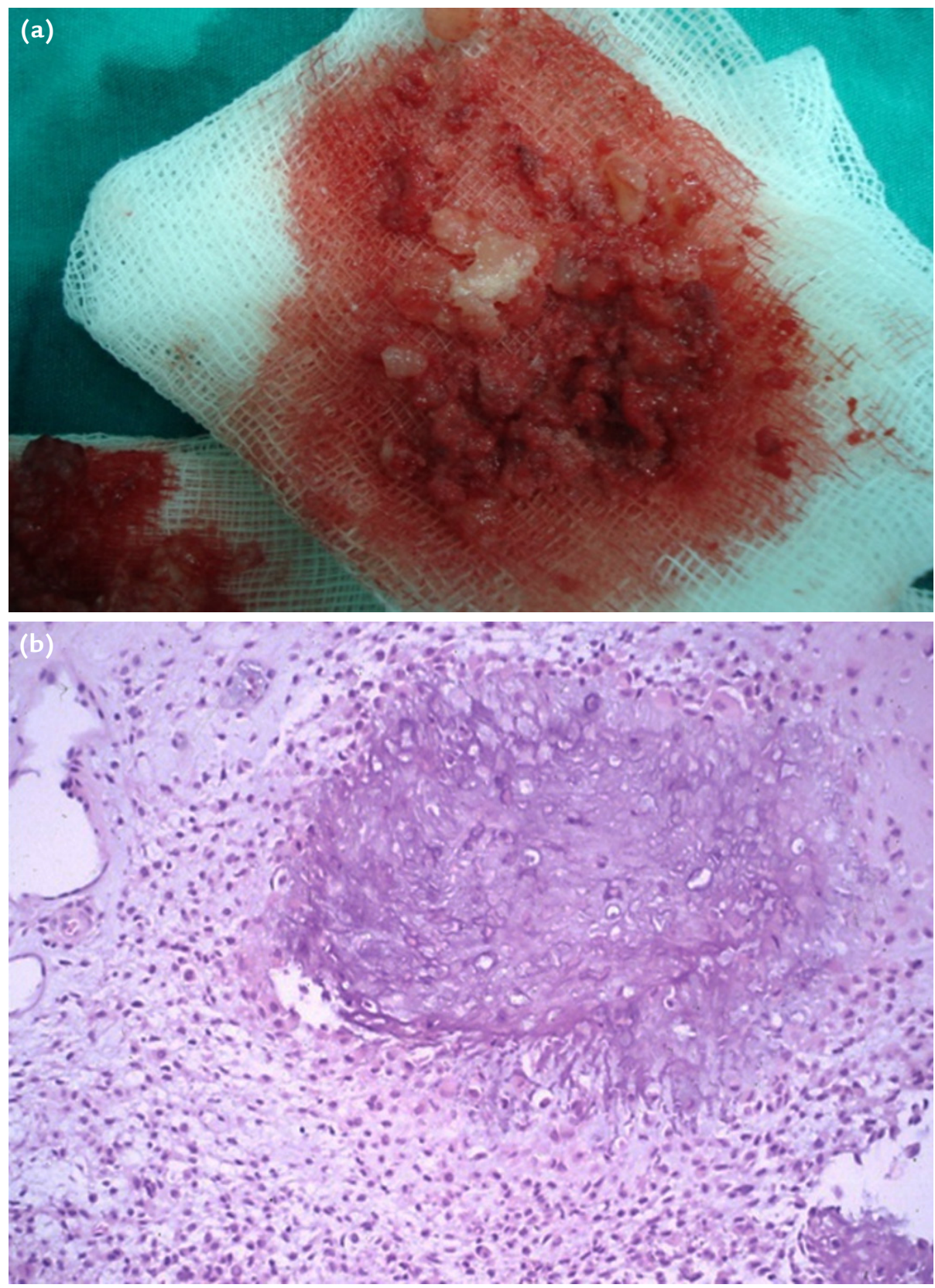

Şekil 8. a, b. Kondromiksoid fibromun makroskopik görünümü. Yer yer kanama alanları gösteren, yarı saydam, kıkırdak benzeri görünüm (a). Mikroskopik olarak kondroid ve miksoid ara madde içinde yerleşmiş hücreden zengin alanlar izleniyor (b).

\section{KAYNAKLAR}

1. Greenspan A, Remagen W. Differential Diagnosis of Tumors and Tumor-Like Lesions of Bones and Joints $1 \mathrm{st}$ ed. Philadelphia: Lippincott-Raven; 1998. p.159-70.

2. Simon MA, Springfield D, editors. Surgery for Bone and SoftTissue Tumors 1st ed. Philadelphia: Lippincott-Raven; 1998. p.190-1.
3. Weber KL, O'Connor MI. Benign Cartilage Tumors. In: Schwartz HS, editor. Orthopaedic Knowledge Update: Musculoskeletal Tumors 2. 2nd ed. Rosemont, IL: American Academy of Orthopaedic Surgeons; 2007. p.114-8.

4. Gitelis S, Soorapanth C. Benign Chondroid Tumors. In: Menendez LR, editor. Orthopaedic Knowledge Update: Musculoskeletal Tumors. 1st ed. Rosemont, IL: American Academy of Orthopaedic Surgeons; 2002. p.107-9.

5. Campanacci M. Bone and Soft Tissue Tumors. 1st ed. New York-Wien: Springer-Verlag; 1990. p.241-64. 